Document downloaded from:

http://hdl.handle.net/10251/75421

This paper must be cited as:

Casas Moreno, MDM.; Barreto Palacios, VJ.; González Carrascosa, R.; Iborra Bernad, MDC.; Andrés Bello, MD.; Martínez Monzó, J.; García-Segovia, P. (2015). Evaluation of Textural and Sensory Properties on Typical Spanish Small Cakes Designed Using Alternative Flours. Journal of Culinary Science and Technology. 13(1):19-28. doi:10.1080/15428052.2014.952475.

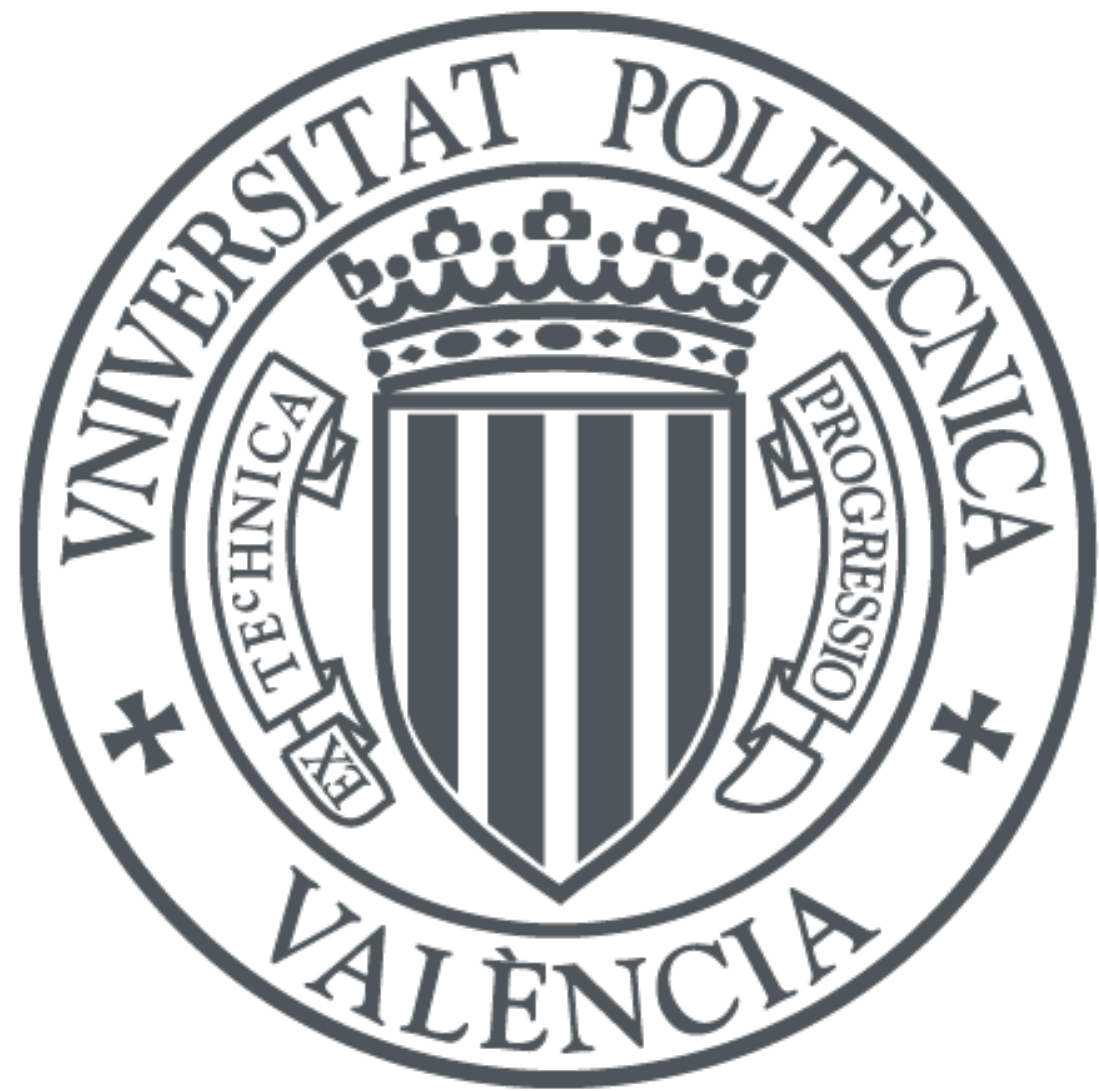

The final publication is available at

https://dx.doi.org/10.1080/15428052.2014.952475

Copyright Taylor \& Francis

Additional Information 


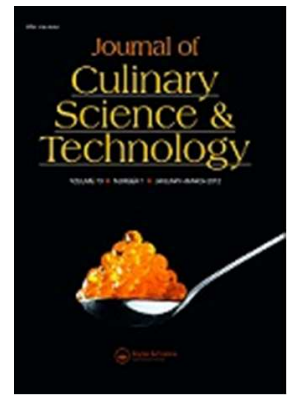

\section{EVALUATION OF TEXTURAL AND SENSORY PROPERTIES ON TYPICAL SPANISH SMALL CAKES DESIGNED USING ALTERNATIVE FLOURS.}

\begin{tabular}{|r|l|}
\hline Journal: & Journal of Culinary Science \& Technology \\
\hline Manuscript ID: & Draft \\
\hline Manuscript Type: & Original \\
\hline Keywords: & $\begin{array}{l}\text { Food product development, Culinary science, Sensory evaluation, Food } \\
\text { science }\end{array}$ \\
\hline \multicolumn{2}{|l}{} \\
\hline
\end{tabular}

\section{SCHOLARONE"}

Manuscripts 


\section{ABSTRACT}

3 The objective of this study was to evaluate the effect of wheat flour substitution by

4 toasted corn, quinoa and sorghum flours on the overall perception and texture of

5 typical Spanish small cakes named madeleine. In order to evaluate these

6 characteristics, a Texture Profile Analysis (TPA) and a sensory analysis were carried

7 out. TPA showed that the replacement of wheat flour by sorghum flour do not

8 affected significantly texture parameters of cakes. Hedonic sensory tests were also

9 conducted revealing that the cake prepared with sorghum flour was highly

10 appreciated by the consumers as it got scores similar to traditional cakes made with

11 wheat flour.

13 Key words: Reformulated madeleine; consumer perception; texture; alternative 14 flour. 


\section{INTRODUCTION}

28 From a commercial perspective, the development of gluten-free cakes with texture

29 and flavor properties similar to the conventional wheat flour may be an interesting

30 objective. Bakery products, particularly cakes, represent as one of the most

31 consumed foods around the world. Sponge cakes, cupcakes, muffins or traditional

32 small cake (madeleine) are connected in the consumer's mind as a delicious product

33 with particular organoleptic characteristics (Matsakidou et al., 2010). The worldwide

34 market of cakes currently grows with about $1.5 \%$ a year. Challenges in this market

35 include cost reduction, increased shelf life and quality control (Wilderjans et al., 36 2013).

37 A cake batter is a complex colloidal system which is processed by being heat set.

38 The baking of cakes leads to a light, aerated structure as well as to the formation of

39 volatile compounds result of the Maillard reaction (Matsakidou et al., 2010).

40 Typical Spanish small cake (madeleine) formulation is composed of wheat flour,

41 sugar, eggs, milk and oil. All these ingredients have different contributions to the

42 sensory quality appreciated by consumers. Knowing interactions between ingredients

43 is possible to predict changes on their characteristics or to reformulate new products

44 (Baixauli Muñoz, 2007).

45 The liquid phase is an essential component of bakery products. Water is added by 46 means of milk (Chiech, 2006). The milk hydrates the starch of the flour, the swollen 47 granules began to expand and gelatinize when heated. Additionally, milk dissolves 
48 other ingredients such as sugar, during whipping and baking (Baixauli Muñoz,

49 2007).

50 In the baking industry, lipids provide characteristics such as tenderness, moist, mouth

51 feel, lubricity, flavor, structure and shelf life (Baldwin et al., 1971; Stauffer, 1998;

52 Wainwright, 1999; Ghotra et al., 2002; Rogers, 2004). The lipids promote the air

53 incorporation during mixing, to give a softer structure and avoid a dry mouth feel.

54 The trapped air bubbles accumulate water vapor and the gas provided by the dough

55 improver expands (Stauffer, 1998; Lai and Lin, 2006; Oreopoulou, 2006).

56 Dough improvers are often added to flour to enhance dough elasticity and baking

57 quality, the most widely used id sodium bicarbonate. It reacts with acids to produce

58 carbon dioxide bubbles (Baixauli Muñoz, 2007).

59 Egg provides interesting functional properties, improving color and appearance to the 60 final product (Conforti, 2006).

61 Sucrose has an important role to play in the development and maintenance of texture 62 (Lindley, 1987). The concentration of sucrose solution in a recipe has a significant 63 effect on the gelatinization temperature of the starch. This has been attributed to 64 sucrose limiting water availability to starch granules and lowering of water activity 65 (Beleia et al., 1996; Spies and Hoseney, 1982).

66 Flour provides structure, texture and flavor to baked products. Starch is one of the 67 components in flour that strengthens the baked item through gelatinization (changes 68 that starch undergoes when subjected to moist heat), and is one of the factors that 69 contributes to crumb. Crumb is partially created during baking by the number and 70 size of air cells produced the degree of starch gelatinization and the amount of 71 protein coagulation (Jacobson, 1997). 
72 Worldwide the most commonly flour used in the bakery industry is the wheat flour

73 as its desirable baking characteristics have been attributed to gluten. In cake recipes,

74 gluten is diluted with eggs, fat and sugar and is therefore less concentrated than in

75 bread dough. Due to the lower viscosity of cake batter than of bread dough, less

76 friction and thus, less energy is exerted on the gluten during mixing (Cauvain \&

77 Young, 2006). Most authors agree that in cake batter, gluten serves as a viscosity

78 enhancing water binder (Donelson \& Wilson, 1960; Wilderjans et al., 2008).

79 Donelson and Wilson (1960) ascribed a greater importance to gluten proteins than to

80 starch in the formation of cake structure. Although the development of a gluten

81 network is limited in cake batter, gluten proteins may become important for cake

82 structure during baking (Kiosseoglou \& Paraskevopoulou, 2006; Wilderjans et al.,

83 2008).

84 Substitution of wheat flour requires finding other flours from beans, rice and the

85 "ancient grains" like amaranth, millet, quinoa, sorghum and teff which do not have

86 gluten. Some of these flours such as teff, quinoa and bean do not generate the same

87 texture, and these alternative flours can generate different flavor profiles (Wilson,

88 2012).

89 Currently, many of the gluten-free cakes that are available in the marketplace are of

90 low quality, exhibiting poor mouth-feel and flavor (Peressini et al., 2012). The

91 gluten- and allergen-free bakery industry typically must select from a broad range of

92 ingredients to achieve the same level of functionality as in conventional formulas.

93 During gluten-free baking, these ingredients need to replace the attributes that gluten

94 lends to breads or baked products. When formulating products with gluten-free flour,

95 moisture content is critical. If baking an item that is expected to rise and the dough is 
96 dry, it will be too dense. If the dough is too moist, the rise will be good but it will

97 collapse during breaking (Martínez-Monzó et al., 2013).

98 In the current work the textural and sensory properties in reformulated typical small

99 Spanish cakes (madeleine) were studied with the aim to correlated consumer

100 preferences with objective physic-chemical properties.

\section{MATERIALS AND METHODS}

\subsection{Flour for madeleine}

104 Sorghum, quinoa and toasted corn flours (Moli Muntada S.L., Barcelona, Spain)

105 were used like alternative flours. Wheat flour (Harinera Castellana, Medina del 106 Campo, Spain) was used as control.

\subsection{Batter Preparation and Baking}

108 Batter was prepared from flour, sucrose (Azucarera Española, Valladolid, Spain), 109 fresh whole milk (Grupo Leche Pascual S.A., Burgos, Spain), sodium chloride, 110 refined vegetable oil (Koipesol, Madrid, Spain), whole eggs (La receta, Madrid, 111 Spain) and baking powder (Martínez, Cheste, Spain). The ingredients were mixed in 112 a Kenwood Major Classic mixer (New Lane, Havant, UK), as described by Sanz et 113 al. (2009). The eggs white was initially whipped in the mixer for 2 min until stiff 114 peaks form. In another bowl the egg yolk and sucrose was beaten until creamy 115 smooth. The milk and oil were added and the batter was beaten for 2 minutes. 116 Gradually the flour and baking powder were added to the batter. Finally the stiff egg 117 white was added and the mixture. Baking was carried out at $150^{\circ} \mathrm{C}$ for $12 \mathrm{~min}$ in a 118 mini combi oven steamer OES 6.06 (Convotherm, Manitowok, Eglfing, Germany). 119 The procedure was replicated three times on separate days, and average values were 
120 reported. Samples after baking were cooled to room temperature for about $1 \mathrm{~h}$ before 121 sensory and instrumental texture measurements.

\subsection{Texture Profile Analysis (TPA)}

123 TPA was performed using a Texture Analyzer Model TA-XTplus (Stable Micro 124 Systems, Ltd., England). An aluminum cylindrical probe was used in a compression 125 test to compress each sample to $35 \%$ of its original height with a cross head speed of $12620 \mathrm{~mm} \mathrm{~s}-1$, compression force of $10 \mathrm{~N}$. The Texture Exponent Lite 32 (Vs. 4.9.8.0) 127 software program was used to quantify parameters: hardness (g), adhesiveness ( $\mathrm{g} \mathrm{x}$ 128 s), springiness, cohesiveness, gumminess and chewiness.

\subsection{Sensory Analysis}

130 On the sensory analysis, 87 panelists aged from 17 to 25 were recruited in 131 Universitat Politècnica de València. Panelists tasted and described attributes: 132 appearance, color, flavor, sponginess, texture, taste, after-taste, global acceptance.

133 For samples were examined (1 control and 3 alternative flours) in one hour session.

134 Each attribute was rated on a nine-point hedonic scale ranging from 1 (dislike 135 extremely) to 9 (like extremely). Madeleine samples were coded with 3-digit random 136 numbers and presented monadically. Samples were presented following a balanced 137 complete block design. Water was provided for rinsing during the session.

\section{$138 \quad$ 2.5.Statistical Analysis}

139 All determinations were made in triplicate. Data were analyzed using one-way 140 analysis of variance. The mean comparison was carried out using Statgraphic 141 Centurion XVI (Statpoint Technologies, Inc., Warrenton, Virginia, USA).

\section{RESULTS AND DISCUSION}




\subsection{Texture}

145 Changes in texture obtained from TPA of madeleine with wheat and alternative flour

146 are shown in Fig.1. Means with same letters in same attribute are not significantly

147 different $(p>0.05)$. Each texture parameters were described separately and then a

148 comparison was made between madeleine prepared with wheat flour and those made

149 with alternative flours.

150 Springiness, noted as elasticity, reflects how much the structure of tested gel is

151 broken down by the initial compression. High springiness gel results in few large

152 pieces during the first TPA compression whereas low springiness gel results in more

153 small pieces (Lau et al., 2000). Cohesiveness measures the difficulty of breaking

154 down the internal structure of gel. Gumminess, as the product of hardness and

155 cohesiveness, usually is a complementary parameter of hardness (Zhu et al., 2008).

156 The parameters hardness and gumminess did not result in statistically significant 157 differences $(\mathrm{p}>0.05)$ between different flours analyzed. Although, in both 158 parameters, the values were lower in sorghum formulations.

159 Quinoa flour showed significant differences $(\mathrm{p} \leq 0.05)$ in chewiness compared to 160 wheat.

161 Instrumental adhesiveness show statistically significant difference $(p \leq 0.05)$ between 162 toasted corn and other flours.

163 Cohesiveness results showed significant differences $(\mathrm{p} \leq 0.05)$ for the different flours. 164 Toasted corn and sorghum madeleine were less cohesive than others; it would 165 explain the values obtained in the sensory results where these samples were less 166 valued in mouth texture. 
167 Non-significant differences were found in all textural attributes between sorghum 168 and control wheat madeleines.

$169 \quad$ 3.2.Sensory Analysis

170 In the sensory tests, fifty-four percent of the participants were female and the 171 subjects were between 17 and 25 years old. Table 1 presents the basic statistics 172 referring to the data collected using the 9-point scale.

173 In all attributes evaluated, wheat flour madeleine was the highest scored. Those 174 results were expected as wheat flour is widely used in the bakery industry and the 175 consumers are related with its sensory characteristics.

176 Organoleptic evaluation of madeleine, as shown in fig. 2, revealed that, to the global 177 acceptance, wheat madeleine achieved higher scores (7.01 \pm 1.44$)$, followed by 178 sorghum $(5.85 \pm 1.41)$, quinoa $(5.79 \pm 1.66)$ and toasted corn $(4.78 \pm 1.71)$.

179 Sorghum was second on preference. This result must be correlated with obtained in 180 textural properties since the difference in the TPA between sorghum and wheat flour 181 did not reach statistical significance $(\mathrm{p}>0.05)$.

182 Color in sorghum flour madeleine was more dark brown than wheat flour. These 183 differences were statistically significant $(\mathrm{p} \leq 0.05)$ by consumers. Dark colors from 184 black or tannin-containing sorghum varieties might be advantageous in products for 185 the health market (Rooney and Awika, 2005) or in countries where dark, rye-based 186 bread is common (e.g. Germany or Eastern Europe). In such communities, usually 187 "dark" is associated with "healthy" (Taylor et al., 2006). Brannan et al. (2001) 188 found that consumers did accept the color and appearance of a lighter-colored 189 sorghum muffin, resembling a plain or maize muffin as well as a dark brown one, 190 resembling a chocolate, pumpernickel or dark bran muffin. 
191 Whereas appearance, color and sponginess of quinoa and wheat formulations did not 192 differ significantly ( $>0.05)$, taste and after-taste were lower scored for quinoa. This 193 flour has a characteristic flavor not easily recognized by the consumers. 194 Mastromatteo et al. (2011) found that the quinoa constituents bring about a bitter 195 taste that affects negatively the overall acceptability of non-conventional gluten-free 196 fresh and dry pasta.

197 Panelist perceived significant differences ( $\mathrm{p}>0.05$ ) among sponginess provided by 198 the different flours.

199 Consumers expressed their willingness to purchase, intention to consume and 200 recommend each muffin formulation using a dichotomy scale (Fig 3). Consumer 201 were more willing to consume and purchase wheat madeleine $(71.3 \%)$, followed by 202 sorghum (35.6\%), quinoa (31.0\%) and toasted corn (14.9\%). The highest percentage 203 of positive responses in alternative madeleines belongs to sorghum flour, additionally 204 to the highest overall sensory score by consumers and a similar texture than the 205 wheat madeleines.

206

\section{CONCLUSIONS}

208 The obtained results seem to be a good compromise for the choice of products that 209 bring benefits to sensible populations (as celiac). As substitutes of wheat flour in 210 madeleines production, both sorghum and quinoa flours could be a suitable 211 alternative to conventional madeleines based on their organoleptic and textural 212 properties. These results suggest an opportunity for bakery industry to the 213 introduction of new innovative health products through the use of sorghum flour and 214 other alternative flours. 


\section{ACKNOWLEDGEMENT}

217 Authors want to acknowledge to Molí Muntada S.L (Barcelona, Spain) for their 218 collaboration in this work.

\section{REFERENCES}

- Baixauli Muñoz, R. 2007. Influence of the addition of a functional ingredient on the quality of a bakery product. Rheological and textural aspects and its relation to the sensory acceptability. PhD Thesis, October 2007.

- Baldwin, R.R. Baldry, R.P. Johansen, R.G. (1971). Fat systems for bakery products. Journal of the American Oil Chemists' Society, 49, 473-477.

- Beleia, A. Miller, R.A. Hoseney, R.C. (1996). Starch gelatinization in sugar solutions. Starch, 48, 259-262.

- Brannan, G.L. Setser, C.S. Kemp, K.E. Seib, P.A. Roozeboom, K. (2001). Sensory characteristics of grain sorghum hybrids with potential for use in human food. Cereal Chemistry, 78, 693-700.

- Cauvain, S. P., \& Young, L. (2006). Baked products: Science, technology and practice. Oxford, UK: Blackwell Publishing.

- Chiech, C. (2006). Water. In: Hui. Y.H.(Ed) Bakery products: Science and Technology (1st ed). Iowa: Blackwell Publishing

- Conforti, F.D. (2006). Cake Manufacture. In: Hui. Y.H.(Ed) Bakery products: Science and Technology ( $1^{\text {st }}$ ed). Iowa: Blackwell Publishing.

- Donelson, D. H., \& Wilson, J. T. (1960). Effect of the relative quantity of flour fractions on cake quality. Cereal Chemistry, 37, 241-262. 
239 - Gallagher, E. Gormley, T.R. Arendt, E.K. (2004). Recent advances in the

240 formulation of gluten-free cereal-based products. Trends in Food Science and $241 \quad$ Technology, 15, 143-152.

- Ghotra, B.S. Dyal, S.D. Narine, S.S. (2002). Lipid shortenings: a review. Food Research International, 35, 1015-1048.

244 - Hager, A.S. Wolter, A. Czerny, M. Bez, J. Zannini, E. Arendt, E.K. Czerny, 245 M. (2012). Investigation of product quality, sensory profile and ultrastructure 246 of breads made from a range of commercial gluten-free flours compared to 247 their wheat counterparts. European Food Research and Technology, 235, $333-344$

249 - Jacobson, K.A. (1997). Whey protein concentrates as functional ingredients $250 \quad$ in baked goods. Cereal Foods World, 42(3), 138-141.

251 - Kiosseoglou, V., \& Paraskevopoulou, A. (2006). Eggs. In Y. H. Hui, H. 252 Corke, I. De Leyn, W. Nip, \& N. Cross (Eds.), Bakery products: Science and technology (pp. 161e172). Oxford, UK: Blackwell Publishing.

- Lai, H.M., Lin, T.C. (2006). Bakery products: science and technology. In: Hui. Y.H. (ed). Bakery products: Science and Technology.(1 ${ }^{\text {st }}$ d). Iowa: Blackwell Publishing.

- Lau, M.H. Tang, J. Paulson, A.T. (2000). Texture profile and turbidity of gellan/gelation mixed gels. Food Research International, 33, 665-671.

- Lindley, M.G. (1987). Sucrose in baked products. Nutrition Bulletin, 12(1), $41-45$. 
261 - Martínez-Monzó, J. García-Segovia, P. Alborns-Garrigos, J. (2013). Trends

262 and innovations in bread, bakery and pastry. Journal of Food Science and 263 Technology, 11(1), 56-65.

264 - Mastromatteo, M. Chillo, S. Iannetti, M. Civica, V. Del Nobile, M.A. (2011).

265 Formulation optimization of gluten-free functional spaghetti based on quinoa, 266 maize and soy flours. International Journal of Food Science and Technology, $267 \quad 46,1201-1208$.

268 - Matsakidou, A. Blekas, G. Paraskevopoulou, A. (2010). Aroma and physical 269 characteristics of cakes prepared by replacing margarine with extra olive 270 virgin olive oil. Food Science and Technology, 43(6), 949-957

271 - Oreopoulou, V. (2006). Fat replacers. En: Hui. Y.H. (Ed). Bakery products: $272 \quad$ Science and Technology (1 $1^{\mathrm{a}}$ ed $)$. Iowa: Blackwell Publishing.

273 - Peressini, D. Pin, M. Sensidoni, A. (2012). Rheology and breadmaking 274 performance of rice-buckwheat batters supplemented with hydrocolloids. $275 \quad$ Food Hydrocolloids, 25, 340-349.

276 - Rogers, D. (2004). Functions of fats and oils in bakery products. Inform $277 \quad$ AOCS, $15,572-574$.

278 - Rooney, L.W. Awika, J.M. (2005). Overview of products and health benefits 279 of specialty sorghums. Cereal Foods World, 50, 109-115.

280 - Sanz, T. Salvador, A. Baixauli, R. Fiszman, S.M. (2009). Evaluation of four 281 types of resistant starch in muffins. II. Effects in texture, color and consumer 282 response. European Food Research and Technology, 229, 197-204.

283 - Spies, R. D. Hoseney, R. C. (1982). Effect of sugars on starch gelatinisation. 284 Cereal Chemistry, 59, 128-131. 
- Stauffer, C.E. (1998). Fats and oils in bakery products. Cereals Food World, 43, 120-126.

- Taylor, J.R.N. Schober, T.J. Bean, S.R. (2006). Novel food and non-food uses for sorghum and millets. Journal of Cereal Science, 44, 252-271.

- Wainwright, B. (1999). Oil and fats for the baking industry. Cereal Foods World, 44, 16-19.

- Wilderjans, E., Pareyt, B., Goesaert, H., Brijs, K., \& Delcour, J. A. (2008). The role of gluten in a pound cake system: a model approach based on gluten-starch blends. Food Chemistry, 110, 909-915.

- Wilderjans, E. Luyts, A. Brijs, K. Delcour, J.A. (2013). Ingredient functionality in batter type cake making. Trends in Food Science and Technology, 30, 6-15.

- Wilson, R.L.W. (2012). How the cookie crumbles: a case of study of glutenfree cookies and random utility. American Journal of Agricultural Economics, 94(2): 576-582.

- Zhu, J.H. Yang, X.Q. Ahmad, I. Li, L. Wang, X.Y. Liu, C. (2008). Rheological properties of K-carrageenan and soybean glycinin mixed gels. Food Research International. 41, 219-228. 
2 Table 1.- Sensory scores of madeleine formulated with different flours.

\begin{tabular}{lcccc}
\hline \multirow{2}{*}{ Attributes } & \multicolumn{4}{c}{ Formulations } \\
\cline { 2 - 5 } & Wheat & Sorghum & Toasted corn & Quinoa \\
\hline Appearance & $7.48 \pm 1.24^{\mathrm{a}}$ & $6.25 \pm 1.59^{\mathrm{b}}$ & $5.59 \pm 1.66^{\mathrm{c}}$ & $7.41 \pm 1.28^{\mathrm{a}}$ \\
Color & $7.40 \pm 1.26^{\mathrm{a}}$ & $6.60 \pm 1.43^{\mathrm{b}}$ & $5.72 \pm 1.82^{\mathrm{c}}$ & $7.22 \pm 1.39^{\mathrm{ab}}$ \\
Flavor & $6.43 \pm 1.61^{\mathrm{a}}$ & $5.60 \pm 1.91^{\mathrm{b}}$ & $4.32 \pm 2.03^{\mathrm{c}}$ & $5.69 \pm 1.94^{\mathrm{ab}}$ \\
Sponginess & $6.51 \pm 1.68^{\mathrm{abc}}$ & $6.21 \pm 2.02^{\mathrm{b}}$ & $6.31 \pm 1.71^{\mathrm{abc}}$ & $7.01 \pm 1.75^{\mathrm{c}}$ \\
Texture & $6.91 \pm 1.63^{\mathrm{a}}$ & $5.51 \pm 1.89^{\mathrm{b}}$ & $4.47 \pm 1.96^{\mathrm{c}}$ & $5.93 \pm 1.96^{\mathrm{b}}$ \\
Taste & $6.83 \pm 1.80^{\mathrm{a}}$ & $5.40 \pm 1.90^{\mathrm{b}}$ & $4.20 \pm 2.12^{\mathrm{c}}$ & $4.94 \pm 2.19^{\mathrm{bc}}$ \\
After-taste & $6.68 \pm 1.75^{\mathrm{a}}$ & $5.56 \pm 1.90^{\mathrm{b}}$ & $4.46 \pm 2.20^{\mathrm{cd}}$ & $4.84 \pm 2.15^{\mathrm{bd}}$ \\
Global acceptance & $7.01 \pm 1.44^{\mathrm{a}}$ & $5.85 \pm 1.41^{\mathrm{b}}$ & $4.78 \pm 1.71^{\mathrm{c}}$ & $5.79 \pm 1.66^{\mathrm{b}}$ \\
\hline
\end{tabular}

3 Means with the same letters in the same attributes indicate samples that do not differ 4 significantly $(\mathrm{p}>0,05)$. These results were obtained using the One-Way ANOVA. 


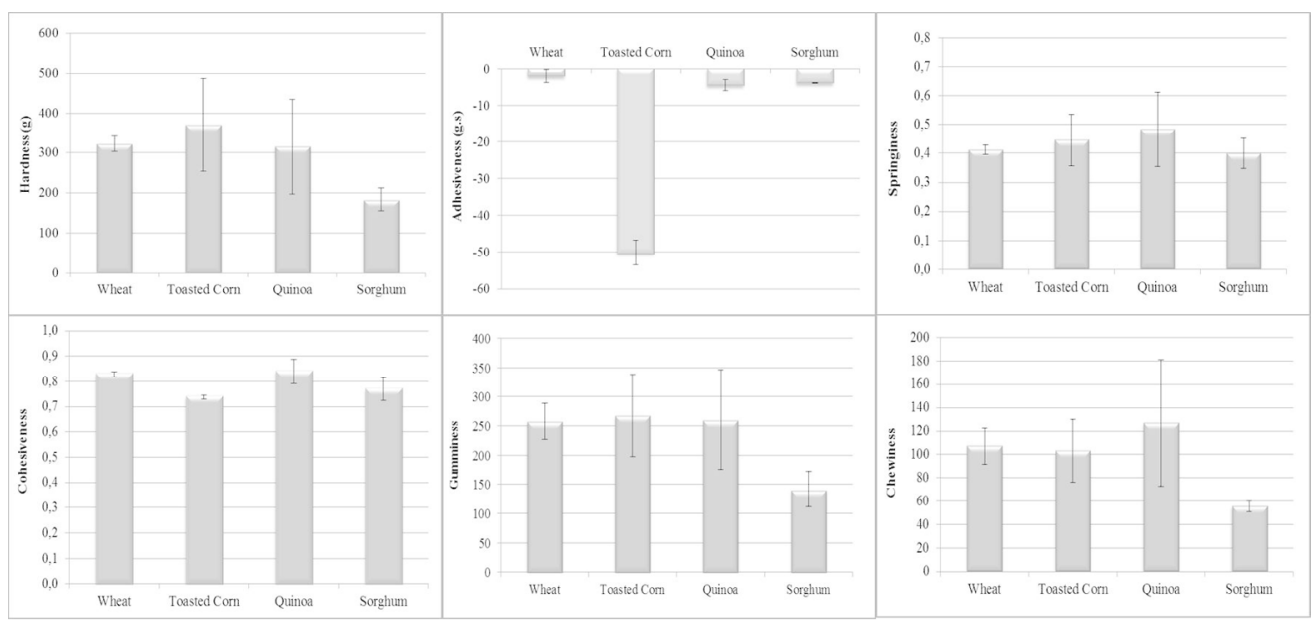

Textural properties $300 \times 139 \mathrm{~mm}(150 \times 150 \mathrm{DPI})$ 


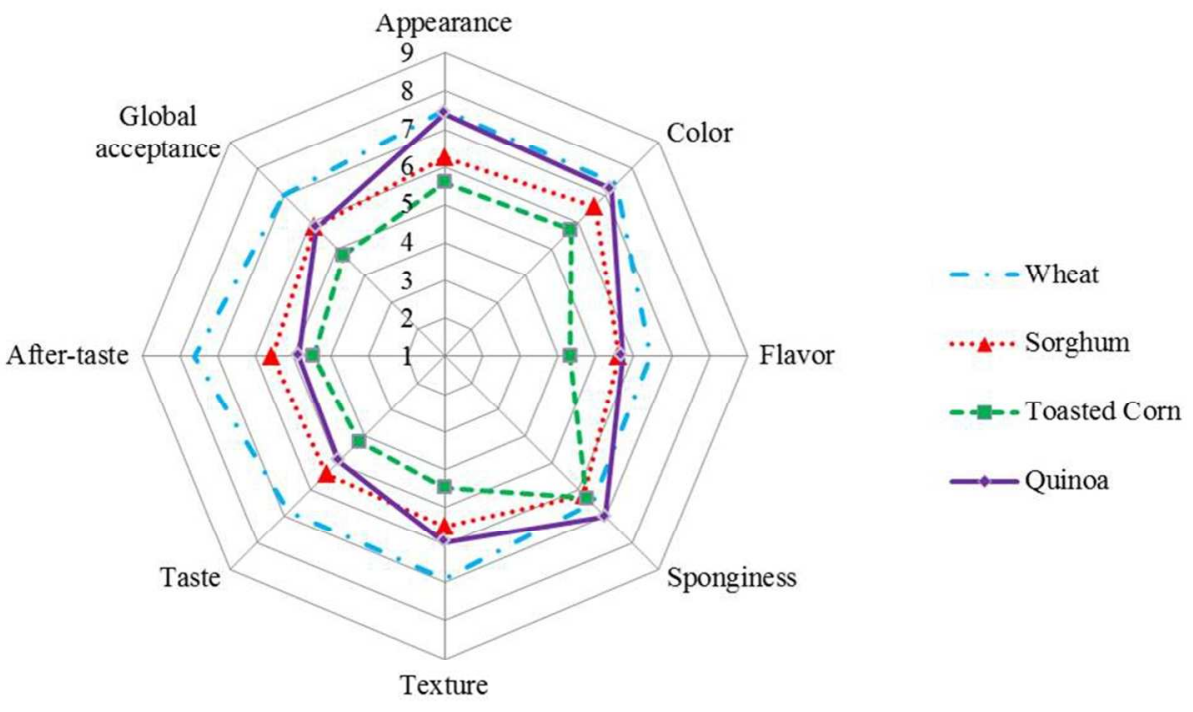

Radar chart of attributes evaluated $175 \times 121 \mathrm{~mm}(150 \times 150 \mathrm{DPI})$ 


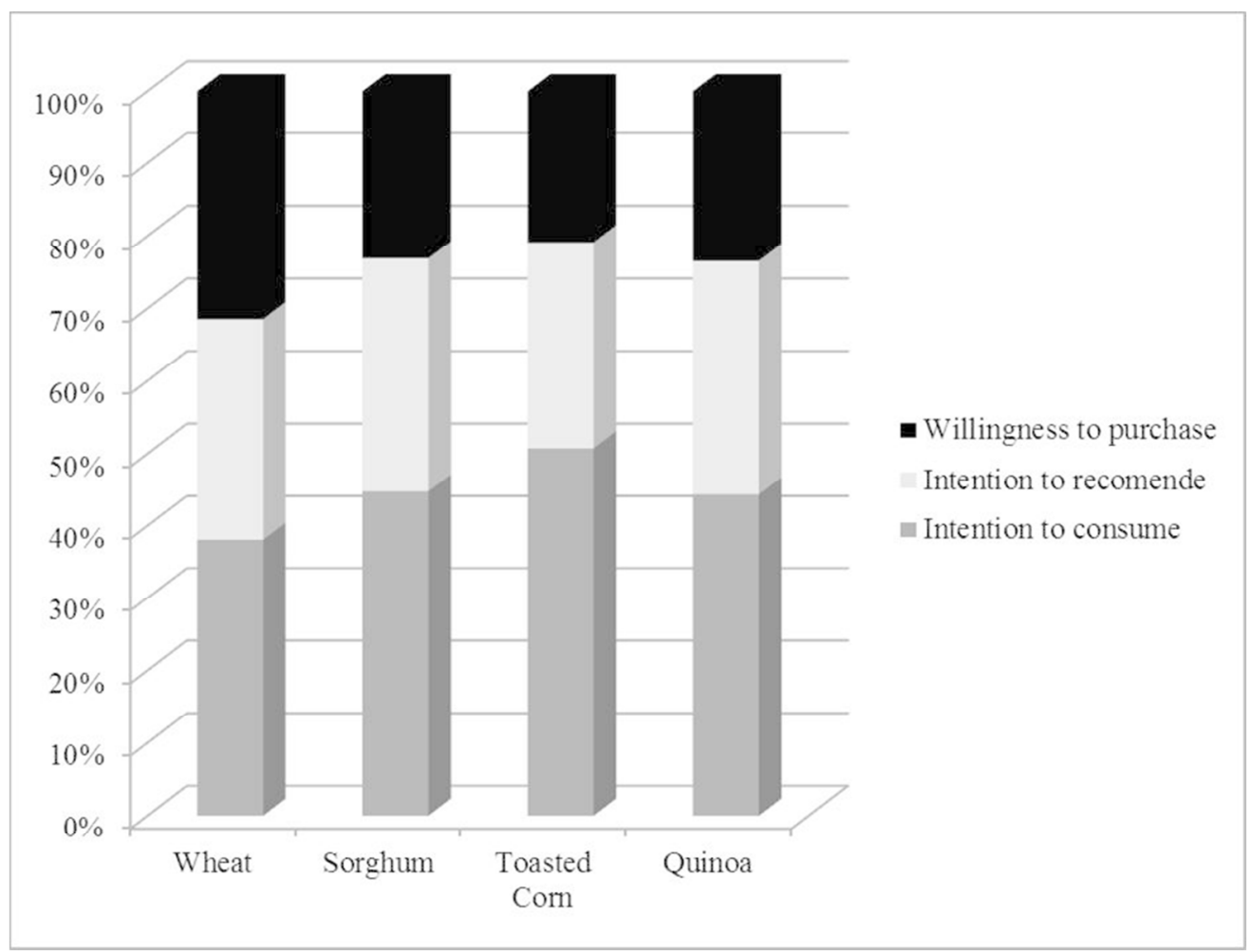

Consumer responses to questions about moment of consumption $157 \times 119 \mathrm{~mm}(150 \times 150 \mathrm{DPI})$

URL: http://mc.manuscriptcentral.com/wcsc Email: rharring@uark.edu 